\title{
The Effect of Hot-Cold Applications on Patellar Tendon to Torque-Time Parameters
}

\section{Patellar Tendon Üzerine Sıcak-Soğuk Uygulamalarının Tork- Zaman Parametrelerine Etkisi}

\author{
Yurdagül Baygül Atalay ${ }^{1}$, Abdullah Meriç Ünal ${ }^{2}$, Ahsen Oğul ${ }^{2}$, Sabriye Ercan ${ }^{3}$, Cem Çetin ${ }^{2}$
}

${ }^{1}$ Sports Medicine Department, Isparta City Hospital, Isparta, Turkey

${ }^{2}$ Sports Medicine Department, Faculty of Medicine, Süleyman Demirel University, Isparta, Turkey

${ }^{3}$ Sports Medicine Department, Dr. Ersin Arslan Education and Research Hospital, Gaziantep, Turkey

Y. B. Atalay

0000-0003-3695-5995

A. M. Ünal

0000-0001-9576-5994

A. Oğul

0000-0001-7379-0750

S. Ercan

0000-0001-9500-698X

C. Çetin

0000-0002-8151-9554

Geliş Tarihi / Date Received: 24.04.2018

Kabul Tarihi / Date Accepted: 27.05.2018

Yayın Tarihi/Published Online: 22.08.2018

\section{Yazışma Adresi /}

Corresponding Author:

Yurdagül Baygül Atalay Isparta Şehir Hastanesi, Spor Hekimliği, Isparta, Türkiye

E-mail: ybay11@hotmail.com

C2018 Türkiye Spor Hekimleri Derneği. Tüm hakları saklıdır.

\section{ABSTRACT}

Objective: Therapeutic use of thermal agents such as hot-cold is common in clinical practice and rehabilitation applications. Changes in tissue temperature create a therapeutic effect by making alterations in metabolism, neurotransmission, hemodynamics and mechanical properties. In this study, the effects of hot-cold applications on patellar tendon to torque-time parameters were investigated.

Materials and Methods: 30 healthy individuals (16 males, 14 females) at the age of 18-30 years were participated to the study. Participants' demographic characteristics were recorded, body weight and height measurements were performed, and Tegner activity scores were noted. Hot and cold applications have been applied to the participants with 48 hours of interval.

Following 5 minutes of submaximal warming exercise in cycle ergometer, patellar tendon temperatures were measured with infrared thermometer and thermal camera. Isokinetic strength tests (concentric mode at $60 \%$ second and $180 \% /$ second) were performed. Hot or cold applications were performed on patellar tendon for 30 minutes. The submaximal warmup exercise repeated following the application, temperature measurements and isokinetic tests were performed again. All tests were performed on dominant lower extremity of the participants.

Results: Statistically significant results were obtained both at infrared thermometer $(p<0.001)$ and also at thermal camera measurements $(p<0.001)$ in the pre-post cooling and heating temperature evaluations.

Time to peak torque and rate of peak torque development were similar in pre and post cold measurements $(p>0.05)$, whereas time to peak torque was significantly lower $(p<0.05)$ and significant increase in rate of peak torque development $(p<0.01)$ has been determined following hot application.

Conclusion: Heat application on patellar tendon may improve athletic performances that require explosive force. There is need for more comprehensive studies to validate the findings obtained by this study.

Key Words: Patellar ligament, cold-hot application, thermography, isokinetic strength. 


\section{öz}

Amaç: Klinikte ve rehabilitasyon uygulamalarında sıcak-soğuk gibi termal ajanların tedavi amaçlı kullanımı yaygın uygulamalardır. Doku sıcaklığındaki değişimler metabolizma, sinir iletimi, hemodinami ve mekanik özelliklerde değişiklik yaparak teröpatik etki oluşturmaktadır. Bu çalışmada patellar tendon üzerine sıcak-soğuk uygulamalarının tork-zaman parametrelerine etkisi araştırılmıştır.

Gereç ve Yöntemler: Çalışmaya 18-30 yaş aralığında, sağlıkı 30 gönüllü (16 erkek, 14 kadın) dahil edildi. Katılımcıların demografik özellikleri kaydedildi, vücut ağırlığı ve boy ölçümleri yapıldı, Tegner aktivite skorları belirlendi.

Tüm gönüllülere 48 saat arayla sıcak ve soğuk uygulama yapıldı. Bisiklet ergometresinde 5 dakika submaksimal ısınma egzersizi sonrası infrared termometre ve termal kamera ile patellar tendon sıcaklıkları ölçüldü ve izokinetik testler (konsantrik modda $60 \%$ saniye ve $180 \%$ saniye) uygulandı. Sonrasında, patellar tendon üzerine 30 dakika sıcak veya soğuk uygulama yapıldı. Uygulama sonrası submaksimal ısınma egzersizi tekrarlandı, ardından sıcaklık ölçümleri ve izokinetik testler yapıldı. Tüm testler katılımcının dominant alt ekstremitesinde uygulandı.

Bulgular: Soğuk uygulama öncesi-sonrası ve sıcak uygulama öncesi-sonrası sıcaklık değerlendirmelerinde hem infrared termometre ölçümlerinde $(p<0.001)$ hem de termal kamera ölçümlerinde $(p<0.001)$ istatistiksel anlamlı sonuçlar elde edildi.

Zirve torka ulaşma zamanı ve zirve tork geliştirme hızı soğuk uygulama öncesi-sonrası ölçümlerde değişmezken ( $p>0.05)$, sıcak uygulama sonrası zivve torka ulaşma zamanında kısalma $(p<0.05)$ ve zirve tork geliştirme hızında artma $(p<0.01)$ saptandı.

Sonuç: Patellar tendona sıcak uygulanması özellikle patlayıcı kuvvet gerektiren atletik performanslarda iyileşme sağlayabilir. Bu çalışmanın bulgularının geçerlilik kazanması için daha geniş kapsamlı çalışmalara gereksinim vardır.

Anahtar Sözcükler: Ligamentum patellae, soğuk-sıcak uygulama, termografi, izokinetik kuvvet

Available at: http://journalofsportsmedicine.org and http://dx.doi.org/10.5152/tjsm.2018.104

Cite this article as: Atalay YB, Unal AM, Ogul A, et al. The effect of hot-cold applications on patellar tendon to torque-time parameters. Turk J Sports Med. 2018;53(4):152-9.

\section{GíRiş}

Klinikte ve rehabilitasyon uygulamalarında sıcak-soğuk gibi termal ajanların tedavi amaçlı kullanımı yaygın uygulamalardır. Doku sıcaklığındaki değişimler metabolizma, sinir iletimi, hemodinami ve mekanik özelliklerde değişiklik yaparak teröpatik etki oluşturmaktadır (1).

Egzersiz öncesi yumuşak dokuların ısıtılması pratikte kullanılan bir yöntemdir. Bu durum aktif ısınma ya da lokal sıcak uygulamaları ile sağlanmaktadır. Isıtma kas ve diğer kollajenöz dokuların viskoelastik özelliklerini artırmakta ve fiziksel aktiviteye hazırlık sağlamaktadır (1).

Soğuk uygulamalar akut yaralanmalarda ve egzersiz sonrası toparlanma amaçlı kullanılmaktadır. Günümüzde, oluşabilecek termal hasar ve yorgunluğu dengelemek amaciyla egzersiz öncesi soğuk uygulamaları da önem kazanmaktadır (1).

Kas-kemik bağlantılarını sağlayan tendonlar kontraktil gücün iletiminde önemli role sahiptir. Tendonlar kemiğe çekme yükü ileterek eklem hareketini sağlar ve eklemin kararlılığını destekler, ayrıca vücudun duruşunu sürdürmeye katkıda bulunurlar. Tendonlar ve kaslardan oluşan miyotendinöz yapılar dinamik bir kısıtlayıcı olarak işlev yapar ve kas uzunluğunun artmasına gerek kalmadan kasların önceden konumlanmasina izin verirler.

Young'ın elastik modülü doku sertlik ölçü birimi olarak kullanılmaktadır. Uygulanan basıncın gerilim (kuvvetin neden olduğu boyut ya da şekil değişikliği) miktarına oranı olarak tanımlanabilir (2). Wang ve arkadaşları bağ dokusu sıcaklığı ile doku sertliği arasında ilişki göstermişlerdir (3).

Sıcaklıkla birlikte elastik modüldeki değişimler kollajen fibrillerinin mekanik özelliklerine bağlanabilir. Gevorkian ve arkadaşlarının yaptıkları çalışmalarda, mikrofibrilleri oluşturan tip 1 kollajeninin fizyolojik şartlarda termal olarak stabil olmadığını göstermeleri bu durumu desteklemektedir (4).

Non-kontakt termal görüntüleme eklem patolojileri, alt bacak patolojileri, vücuttaki termal paternlerin simetri analizleri, cerrahi sonrası inflamasyon monitörizasyonu gibi birçok alanda kullanılmakla birlikte, cilt sıcaklığı 
ölçümlerinde de geçerli ve güvenilir bir yöntem olarak kullanılmaktadır (5).

Termal görüntüleme ve infrared termometre ölçümlerinin diğer kontakt termografi yöntemleriyle karşılaștırıldığında daha efektif oldukları bilinmektedir. İki ölçüm yönteminin etkinliği birbirine yakın olsa da, bazı durumlarda alan sıcaklığ görüntüleme tek nokta ölçümü yapan infrared termometreye üstünlük sağlamaktadır (6).

Birçok atletik aktivitede kısa süre içinde tork geliştirebilmek daha iyi performans sağlamaktadır. Geleneksel yöntemlerde bireysel performans ölçümlerinde üretilen maksimum tork dikkate alınırken, maksimum torka ulaşmak için geçen sürenin de özellikle patlayıcı güç gerektiren boks, sprint, sıçrama gibi spor aktivitelerinde önem kazandığı bilinmektedir (7). Tork gelişim hızı (TGH) tork-zaman eğrisinin yükseliş hızı olarak ifade edilebilir ve zirve ekstansiyon torkunun zirve torka ulaşma süresine bölünmesiyle hesaplanabilir $(8,9)$.

Yine maksimal kuvvetle karşılaştırıldığında, tork gelişim hızının (TGH) nöromuskuler fonksiyonlardaki akut ve kronik değişimlere daha duyarlı olduğunu gösteren yayınlar mevcuttur (10). Direnç egzersizleriyle motor nöron ateşleme frekansında sağlanan artışın, maksimum kontraksiyondan çok TGH'de artışa neden olduğu Aagaard ve arkadaşları tarafından gösterilmiştir (11).

TGH kas alanı, hızlı kasılan liflerin miktarı, miyozin ağır zincir izoform kompozisyonu, efferent motor uyarı büyüklüğü ve muskülotendinoz yapıların sertlik derecesi gibi faktörlerden etkilenmektedir (12).

Eğer tendonlar gerçekten sıcaklık değişimlerine hassas ise, tendon katılığının restore edilmesi atletik performansa etki edebilir. Bu çalışma ile patellar tendon üzerine sıcak-soğuk uygulamalarla elastik modülde öngörülen değişimlerin izokinetik zirve tork, zirve torka ulaşma zamanı, zirve tork geliștirme hızı gibi tork-zaman parametrelerine etkilerinin araştırılması amaçlanmıştır.

\section{GEREÇ VE YÖNTEMLER}

Bu araştırmaya Şubat 2017 ile Nisan 2017 tarihleri arasında Süleyman Demirel Üniversitesi Üniversitesi Tıp Fakültesi Spor Hekimliği Polikliniği'ne başvuran 18-30 yaş aralığında, sağlıklı ve dişlama kriterlerine sahip olmayan 30 gönüllü (16 erkek, 14 kadın) dahil edildi. Dişlama kriterleri;

1. Son iki yıl içinde bacak yaralanması geçirmiş olmak,

2. Maksimal kuvvet testine kontrendike durumu olmak,

3. Nöromusküler, kardiyopulmoner hastalık öyküsü,

4. Soğuk hipersensitivitesi,

5. Dorsalis pedis nabzında anormallik,

6. Alt ekstremite duyu bozukluğu

olarak belirlendi.

Tüm katılımcılara çalışma hakkında bilgi verildi ve imzalanmış Aydınlatılmış Onam Formları alındı. Katılımcıların ayrıntılı fizik muayenesi yapıldıktan sonra çalışma kriterlerine uygun olan kişilerin demografik özellikleri kaydedildi, vücut ağırlığı ve boy ölçümleri yapıldı (SECA 700, Almanya), Tegner aktivite skorları belirlendi.

Çalışmaya katılan tüm gönüllülere sıcak ve soğuk uygulamaların ikisi de yapıldı. Uygulama sırası için kura çektirildi. Sıcak ve soğuk uygulamaları ve testler iki ayrı kişi tarafından uyguland. Bisiklet ergometresinde yapılan $5 \mathrm{dk}$ submaksimal ısınma egzersizi sonrası infrared termometre ve termal kamera ile patellar tendon sıcaklıkları ölçüldü ve izokinetik dinamometre (HUMAC@ NORM ${ }^{\mathrm{TM}}$ Testing \& Rehabilitation System Model 770, USA) kullanılarak diz ekstansörlerinin Zirve Tork (PT) (konsantrik modda $60^{\circ}$ /saniye hızda 5 tekrar), başlangıç PT (konsantrik modda $180^{\circ}$ /saniye hızda 15 tekrar) ve Zirve Torka Ulaşma Zamanı ölçümleri yapıldı. Sonrasında, patellar tendon üzerine 30 dakika sıcak veya soğuk uygulama yapıldı. Uygulamalar için içerisinde jel bulunan, $10 \times 10 \mathrm{~cm}$ boyutlarında ve hem sicak hem soğuk olarak kullanılmak üzere üretilmiş paketler kullanıldı. En az 2 saat buzlukta ya da $70^{\circ} \mathrm{C}$ sicak su ka- 
zanında bekletilmiş paketler beze sarılarak patellar tendon üzerine yerleştirildi. 30 dakika uygulamaya devam edildi. Uygulama sonrasinda submaksimal ısınma egzersizi yapıldı ve sıcaklık ölçümleri ile izokinetik testler tekrarlandı. İlk uygulamadan 48 saat sonra, sıcak uygulanan gönüllülere soğuk, soğuk uygulanan gönüllülere sıcak uygulama yapılarak tüm katılımcılarda her iki uygulama da yapılmış oldu. Tüm testler katılımcının dominant alt ekstremitesinde gerçekleştirildi.

Termal görüntüler oda sıcaklığı 22-25 santigrat derecede sabit tutulan, katılımcı üzerinde direkt hava akımının olmadığı, güneş ışınlarına maruz kalınmayan bir ortamda alındı. Gönüllüler oda sıcaklığına uyum sağlayabilmeleri için protokol öncesi 15 dakika bekletildi.

Görüntüleme için $60 \mathrm{~Hz}$ görüntü frekansına sahip, görüntülerin bilgisayar ortamına aktarılması ve değerlendirilmesini sağlayan yazılımı olan, insan vücudunun ışıma gücü olan 0,98 ع'de çalışabilen, 7,5-13 $\mu \mathrm{m}$ spektral aralıklı, kolay taşınabilir, hafif bir termal kamera olan Thermacam P25 (Flir, USA) kullanıldı. Termal görüntüler 0,8 metre uzaklıktan koronal olarak alındı.

Termal görüntüler, analiz programı yardımı ile bilgisayar ortamında değerlendirildi (Grayess ${ }^{\circledR}$ IRT Analyzer, Version 6.0). En sicak ve en soğuk, birbirine en az 5 piksel uzaklıkta, 25 piksellik alanların ortalamasını veren 5 değer belirlendi. Bunların da ortalaması alınarak tek bir sıcaklık değerine ulaşıldı.

İnfrared termometre olarak ThermoScope HTF03A (Medicare, Çin) kullanıldı. Ölçümler patellar tendon orta bölgesinden ve cilde $1 \mathrm{~cm}$ uzaklıktan yapıldı.

Bu araştırma Süleyman Demirel Üniversitesi Tıp Fakültesi Etik Kurulu'nun 21.12.2016 tarihli toplantısının 177 sayılı kararı ile onaylanmıștır.

\section{İstatistiksel Değerlendirme}

İstatistiksel değerlendirme SPSS 22 versiyonu paket programı kullanılarak yapıldı. İlk olarak verilerin frekans dağılımı incelendi. Tanımlayıcı istatistik veriler ortalama \pm standart sapma olarak verildi.

Verilerin normal dağılıma uygun olduğu 'Kolmogorov-Smirnov testi' ile belirlendi. Başlangıç ve kontrol verilerindeki değişim "Bağımlı gruplarda t testi” ile değerlendirildi.

$\mathrm{p}<0,05$ düzeyindeki sonuçlar anlamlı kabul edildi.

\section{BULGULAR}

30 gönüllü (16 erkek, 14 kadın) ile çalışma tamamlandı. Katılımcıların yaş ortalaması $22 \pm 2$ yıl, boy ortalaması $172 \pm 9 \mathrm{~cm}$, vücut ağırlığı ortalaması $66 \pm 15 \mathrm{~kg}$ ve Tegner aktivite düzeyleri ortalaması $3 \pm 1$ olarak belirlendi.

Soğuk uygulama öncesi ve sonrası sıcaklık değerlendirmelerinde hem infrared termometre ölçümlerinde $(p<0,05)$ hem de termal kamera ölçümlerinde $\quad(p<0,05)$ istatistiksel anlamlı sonuçlar elde edildi (Tablo 1). Benzer şekilde, sıcak uygulama öncesi ve sonrası sonuçlarda da her iki ölçüm yönteminde anlamlı değişiklik görüldü $(\mathrm{p}<0,05)$ (Tablo 2$)$.

İzokinetik parametrelerden olan ekstansör zirve tork (PT) ve zirve tork/ vücut ağırlığı (PT/VA) değerlerine bakıldığında, hem soğuk uygulama öncesi ve sonrası, hem de sıcak uygulama öncesi ve sonrası ölçümlerde istatistiksel anlamlı fark görülmedi ( $p>0,05) .180^{\circ} / \mathrm{s}$ açısal hızda yapılan ilk üç ekstansör PT değeri ortalamasında (IPT) her iki uygulama öncesi ve sonrası değerlendirmelerde istatistiksel anlamlı fark saptanmadı ( $p>0,05)$. (Tablo 1, Tablo 2)

Zirve torka ulaşma zamanı ve zirve tork geliştirme hızı soğuk uygulama öncesi ve sonrası ölçümlerde değişmezken; sıcak uygulama sonrası zirve torka ulaşma zamanında kısalma $(p<0,05)$ ve zirve tork geliștirme hızında artma ( $\mathrm{p}<0,01$ ) saptandı. (Tablo 2)

Soğuk uygulama öncesinde ve sıcak uygulama öncesinde değerlendirilen izokinetik ölçüm parametreleri arasında istatistiksel anlamlı fark saptanmadi. 
Tablo 1. Başlangıç ve soğuk uygulama sonrası ölçüm parametrelerinin bağımlı gruplarda t-testi ile istatistiksel analizi

\begin{tabular}{|c|c|c|c|}
\hline$n=30$ & SOUÖD & SOUSD & p değeri \\
\hline İnfrared termometre $\left({ }^{\circ} \mathrm{C}\right)$ & $30,8 \pm 1,3$ & $16,3 \pm 4,6$ & $<0,001^{*}$ \\
\hline Termal kamera $\left({ }^{\circ} \mathrm{C}\right)$ & $31,5 \pm 1,2$ & $16,6 \pm 4,4$ & $<0,001^{*}$ \\
\hline Ekstansör PT (Nm) $\left(60^{\circ} / \mathrm{s}\right)$ & $138,3 \pm 57,8$ & $134,6 \pm 54$ & 0,293 \\
\hline Ekstansör PT/ VA (Nm) $\left(60^{\circ} / \mathrm{s}\right)$ & $202,7 \pm 50$ & $198,4 \pm 51,5$ & 0,358 \\
\hline Zirve torka ulaşma zamanı (s) & $0,65 \pm 0,15$ & $0,64 \pm 0,17$ & 0,715 \\
\hline Zirve tork geliştirme hızı (Nm/s) & $333,5 \pm 125,4$ & $334 \pm 125,6$ & 0,972 \\
\hline Ekstansör İPT $(\mathrm{Nm})\left(180^{\circ} / \mathrm{s}\right)$ & $87,4 \pm 38,1$ & $88 \pm 39,8$ & 0,809 \\
\hline
\end{tabular}

Tablo 2. Başlangıç ve sıcak uygulama sonrası ölçüm parametrelerinin bağımlı gruplarda t-testi ile istatistiksel analizi

\begin{tabular}{|c|c|c|c|}
\hline$n=30$ & SIUÖD & SIUSD & p değeri \\
\hline Infrared termometre $\left({ }^{\circ} \mathrm{C}\right)$ & $30,2 \pm 1,4$ & $36,8 \pm 1,3$ & $<0,001^{*}$ \\
\hline Termal kamera $\left({ }^{\circ} \mathrm{C}\right)$ & $30,9 \pm 1,1$ & $36,8 \pm 1,3$ & $<0,001^{*}$ \\
\hline Ekstansör PT $(\mathrm{Nm})\left(60^{\circ} / \mathrm{s}\right)$ & $135,4 \pm 58,4$ & $139,9 \pm 54,4$ & 0,266 \\
\hline Ekstansör PT / VA (Nm) $\left(60^{\circ} / \mathrm{s}\right)$ & $198,4 \pm 52,7$ & $205,7 \pm 49,9$ & 0,199 \\
\hline Zirve torka ulașma zamanı (s) & $0,65 \pm 0,14$ & $0,61 \pm 0,13$ & $<0,05^{*}$ \\
\hline Zirve tork geliştirme hızı (Nm/s) & $319,5 \pm 127,8$ & $358,5 \pm 138,8$ & $<0,01^{*}$ \\
\hline Ekstansör İPT (Nm) $\left(180^{\circ} / \mathrm{s}\right)$ & $90,6 \pm 43,6$ & $92 \pm 41,3$ & 0,501 \\
\hline
\end{tabular}

\section{TARTIŞMA VE SONUÇ}

$\mathrm{Bu}$ çalışmada patellar tendon üzerinde sıcak ve soğuk uygulamalarla ortaya çıkması öngörülen elastik modül değişimlerinin izokinetik zirve tork, zirve torka ulaşma zamanı, zirve tork geliştirme hızı gibi tork-zaman parametrelerine etkilerinin araştırılması amaçlanmıştır.

Termal kamera ve infrared termometre ölçümlerinde sıcak ve soğuk uygulama öncesi ve sonrası anlamlı değişimler saptanmıştır. Bu uygulamalar sonrasında her iki açısal hızda zirve tork değerlerinde anlamlı değişim tespit edilmemiştir. Sıcak uygulama sonrası istatistiksel olarak anlamlı seviyede zirve torka ulaşma süresinde kısalma ve zirve tork geliştirme hızında artma saptanmıştır, soğuk uygulamanın bu parametreler üzerine etkisi görülmemiştir.

Non-kontakt termal görüntüleme cilt sıcaklığ ölçümlerinde geçerli ve güvenilir bir yöntem olarak görülmektedir (5).

Termal görüntüleme ve infrared termometre ölçümlerinin diğer kontakt termografi yöntem- 
lerinden daha etkili oldukları bilinmektedir. İki ölçüm yönteminin etkinliği birbirine yakın olsa da bazı durumlarda alan sıcaklığı hakkında bilgi veren termal görüntüleme, tek nokta ölçümü yapan infrared termometreye üstünlük sağlamaktadır (6).

Bu çalışmada iki yöntemle de ölçüm yapılmış ve spot ölçüm değerleriyle termal kamera alan ortalaması değerlerinin yakın olduğu görülmüştür. Daha ucuz ve ulaşllabilir bir cihaz olan infrared termometrenin sicak ve soğuk uygulama sonrası cilt sıcaklığını göstermede etkin olduğu düşünülmektedir.

Enwemeka ve arkadaşları 16 sağlıklı katılımcı ile yaptıkları çalışmada, kuadriseps kası üzerine 20 dakika soğuk uygulaması yapıp, cilt ve cilt altı $1 \mathrm{~cm}, 2 \mathrm{~cm}, 3 \mathrm{~cm}$ derinliğinde doku sicaklık ölçümü yapmıșlardır. Uygulamanın 8'inci dakikasında cilt ve cilt altı $1 \mathrm{~cm}$ uzaklıktaki sıcaklıkta anlamlı düşüş bulmuşlar, daha alttaki tabakalarda değişim görmemişlerdir. 20 dakikalık uygulama sonrasında dört bölgede de anlamlı düşüş tespit etmişlerdir. 40 dakika sonrası kontrolde ise cilt ve $1 \mathrm{~cm}$ cilt altı doku sıcaklığının arttığını, 2 ve $3 \mathrm{~cm}$ derinlikteki dokuların ise yüzeye göre daha soğuk olduğunu tespit etmişlerdir (13).

Dewhurst ve arkadaşları buz torbası ile uyluk üzerine 20-35 dakika soğutma işlemi uygulamışlardır. Cilt sıcaklığında 6 santigrat derece, eş zamanlı ölçülen vastus lateralis subkutan yağlı dokunun $1 \mathrm{~cm}$ altı dokuda 4 santigrat derecelik düşüş sağlamışlardır (14).

Warren ve arkadaşları diz eklemi üzerine 30 dakikalık buz torbası uygulaması sonrasında cilt sıcaklığında 21 santigrat derecelik bir düşüş, eș zamanlı ölçülen intraartiküler sıcaklıkta ise 3,3 santigrat derecelik bir düşüş saptamışlardır (15).

Kime ve arkadaşlarının 30 dakikalık uygulama ardından cilt altı $15 \mathrm{~mm}$ derinlikteki kas sıcaklığını ölçtükleri çalışmada, 3 santigrat derecelik soğuk su immersiyon uygulaması sonrası kas sıcaklığında 3,7 santigrat derece azalma saptamışlardır. 41 santigrat derecede sıcak su immersiyon sonrasinda ise 2,7 santigrat derecelik bir artış kaydetmişlerdir (16).
Muraoka ve arkadaşları da 5-8 santigrat derecede soğuk su immersiyon uygulaması yapıp, süreyi 60 dakikaya uzatmışlar ve intramuskuler sıcaklıkta $5,8 \pm 1,7$ santigrat derecelik bir düşüş sağlamışlardır (17).

Literatürdeki sıcak ve soğuk uygulama çalışmaları daha çok kas ve eklem üzerinedir. Tendon uygulamalarına bakıldığında oldukça sınırlı sayıda çalışmaya ulaşılmıştır.

Selkow ve arkadaşlarının yaptığı çalışmada, aşil tendonu üzerine 20 dakika buz torbası ile soğutma uygulanmış, cilt sıcaklığının 26,1 santigrat dereceden 9,3 santigrat dereceye düştügü, aşil iç sıcaklığının 29,3 santigrat dereceden 16,7 santigrat dereceye düştüğü gözlemlenmiștir (18).

Patellar tendon çalışmalarına bakıldığında, literatürde tek bir çalışma dikkati çekmektedir. Alegre ve arkadaşlarının 20 sağlıklı gönüllünün patellar tendonları üzerinde 30 dakika buz uyguladıkları çalışmada cilt sıcaklığında yaklaşık 17 santigrat derecelik bir düşüş bulmuşlardır (19). Patellar tendon iç sıcaklığını gösteren bir çalışmaya ise ulaşılamamıştır.

$\mathrm{Bu}$ çalıșmada cilt sıcaklığında hem termal kamera ölçümlerinde hem de infrared termometre ölçümlerinde 14,5-15 santigrat derecelik bir düşüş saptanmıştır. Patellar tendonun cilt yüzeyine yakınlığı, vasküler kısıtlılık dikkate alındığında yeterli bir soğutma işlemi yaptığımızı düşünebiliriz. Tendon çalışmaları incelendiğinde karșllașllan bir diğer kavram doku sertliğidir ve çalışmalar bunun üzerine yoğunlaşmıştır. Wang ve arkadaşları bağ dokusu sıcaklığ i ile doku sertliği arasında ilişki olduğunu göstermişlerdir (3).

Price ve Lehman 10 sağlıklı katılımcı ile yaptıkları çalışmada gastroknemius kası üzerine 30 dakika soğuk paket uygulaması yapmış ve kas sertliğinde anlamlı artış gözlemişlerdir (20).

Muraoka ve arkadaşlarının yukarıda bahsedilen çalışmalarında intramuskuler sıcaklıkta 5,8 santigrat derecelik bir düşüş sonrası trisesps surae kas sertliğinde anlamlı artış gösterilmiștir (17).

Soğukla birlikte sertliğin artması kollajen fibrillerinin mekanik özelliklerine bağlanabilir. Gevorkian ve arkadaşlarının yaptıkları 
çalışmalarda mikrofibrilleri oluşturan tip 1 kollajenin fizyolojik şartlarda termal olarak stabil olmadığını göstermeleri bu durumu desteklemektedir (4).

$\mathrm{Bu}$ konudaki tendon çalışmaları yine sınırlılık göstermektedir. Kubo ve arkadaşları 8 sağlıklı gönüllü ile yaptıkları çalıșmada, gastroknemius kas ve tendonuna 5 ve 42 santigrat derecelerde 30 dakika soğuk ve sicak su immersiyon uygulaması sonrası sertlik ölçümleri yapmışlardır. İstatistiksel olarak anlamlı olmasa da elastik modülde artma ve azalma göstermişlerdir (21).

Walker ve arkadaşları köpek aşil ve patellar tendonu üzerine sicak uygulamanın etkisini araştırmışlar ve intratendinöz sıcaklığı 23 santigrat dereceden 49 santigrat dereceye çıkardıklarında elastik modülde anlamlı azalma saptamışlardır (22).

Patellar tendon sıcaklığı ile sertliği arasındaki ilişkiyi inceleyen tek insan çalışması Alegre ve arkadaşlarına aittir (19). Patellar tendon üzerine 30 dakikalık buz uygulaması sonrasında yapılan B-mod ultrasonografik ölçümlerde elastik modülde anlamlı artış saptanmıștır.

Patellar tendon üzerine sıcak uygulama sonrası sıcaklık değişimlerini ve mekanik özelliklerdeki değişiklikleri değerlendiren çalışmalar bulunmamakla birlikte, kas üzerine 20-30 dakikalık sıcak paket ya da immersiyon şeklinde sıcak uygulama sonrası kassal sertlikte anlamlı azalmalar saptayan çalışmalar bulunmaktadır (1).

$\mathrm{Bu}$ çalışmada patellar tendon üzerine sıcak paket uygulama sonrası cilt sıcaklığında yaklașık 6 santigrat derecelik bir artış sağlanmıştır. Bu ölçekteki sıcaklık artışının patellar tendon mekanik özelliklerinde değişikliğe yol açtığını gösteren literatür verisine ulaşılamamıştır.

Kısa süre içinde tork geliştirebilmek çoğu atletik aktivitede daha iyi performans sağlamaktadır. Geleneksel yöntemlerle yapılan bireysel performans ölçümlerinde maksimum tork dikkate alınırken, maksimum torka ulaşmak için geçen sürenin özellikle patlayıcı güç gerektiren boks, sprint, sıçrama gibi spor aktivitelerinde önemli olduğu vurgulanmaktadır (7).

Yine maksimal kuvvetle karşılaştırıldığında, tork gelişim hızının nöromusküler fonksiyonlardaki akut ve kronik değişimlere daha duyarlı olduğunu gösteren yayınlar mevcuttur (10).

TGH, kas alanı, hızlı kasılan liflerin miktarı, miyozin ağır zincir izoform kompozisyonu, efferent motor uyarı büyüklüğü ve muskülotendinöz yapıların sertlik derecesi gibi faktörlerden etkilenmektedir. Kuvvet iletim hızı bir materyalin sertlik derecesiyle ilişkilidir. Bojsen-Moller ve arkadaşları patellar tendon sertlik derecesiyle TGH arasinda anlamlı pozitif ilişki göstermişlerdir. Bu durum sertleşmiş elastik elementlerin kastan kemiğe daha hızlı kuvvet iletimi sağlamasına bağlanmıștır (12).

Bu çalışmada sıcak ve soğuk uygulamaların patellar tendon elastik modülünde yol açtığı öngörülen değişikliklerin zirve torka ulaşma zamanı (PTUZ) ve zirve tork geliştirme hızına (PTGH) etkisi araştırılmıştır.

Soğuk uygulama sonrasında PTUZ ve PTGH parametrelerinde herhangi bir anlamlı değișim saptanmamıștır. Bu durum patellar tendon elastik modülünde yeterli artma sağlansa da, nöral yolaklarda soğuğun oluşturduğu asetilkolin salınımında azalma ve dolayısıyle sinir iletim hızında azalmaya bağlanabilir (23).

Sıcak uygulama sonrasında ise beklediğimizin tersi yönde sonuçlar elde edilmiştir. PTUZ'de azalma ve PTGH'de artış belirlenmiştir. Elastik modülde azalma sonrası hiz parametrelerinde azalma beklerken ulaştığımız bu sonuçlar uyguladığımız ısıtma işleminin yetersizliğine ya da sıcak ile sempatik sinir sistemi iletim hızında artış ve uyarılan golgi tendon organ sayısında artışa bağlanabilir (24).

$\mathrm{Bu}$ çalışmada elde edilen veriler sonucunda;

- Sicak ve soğuk uygulama sonrasında, hem termal kamera hem de infrared termometre ile yapılan ölçümlerde anlamlı değişim saptanmıştır.

- Her iki uygulama sonrasinda maksimal tork değerlerinde anlamlı fark bulunmamıștır.

- Soğuk uygulama sonrasında PTUZ ve PTGH parametrelerinde değişim saptanmazken, sicak uygulama sonrasinda PTUZ'de azalma ve PTGH'de artma saptanmıştır. 
$\mathrm{Bu}$ veriler ışığında, patellar tendonun ısıtılması ile özellikle patlayıcı kuvvet gerektiren atletik performanslarda iyileşme sağlanabileceği öngörülebilir. Kesin yargılara ulaşabilmek için daha kapsamlı çalışmalara gereksinim vardır.

\section{KAYNAKLAR}

1. Bleakley CM, Costello JT. Do thermal agents affect range of movement and mechanical properties in soft tissues? A systematic review. Arch Phys Med Rehabil. 2013; 94(1): 149-63.

2. Yakut Zİ, Turan A, Teber MA. Kas-İskelet Sistem Uygulamalarında Ultrason Elastografi. Selcuk Med J. 2014; 30(2): 88-92.

3. Wang JC, Kabo JM, Tsou PM, et al. The effect of uniform heating on the biomechanical properties of the intervertebral disc in a porcine model. Spine J. 2005; 5(1): 64-70.

4. Gevorkian SG, Allahverdyan AE, Gevorgyan DS, et al. Thermal (in) stability of type I collagen fibrils. Phys Rev Lett. 2009; 102(4): 048101.

5. Selfe J, Hardaker N, Thewlis D, et al. An accurate and reliable method of thermal data analysis in thermal imaging of the anterior knee for use in cryotherapy research. Arch Phys Med Rehabil. 2006; 87(12): 16305.

6. Sherman RA, Woerman AL, Karstetter KW. Comparative effectiveness of videothermography, contact thermography, and infrared beam thermography for scanning relative skin temperature. J Rehabil Res Dev. 1996; 33(4): 377.

7. Kitagawa T. The relationship between rate of torque development of the triple extensors at different time intervals. Thesis for the degree of Master of Science in Exercise and Sport Science. Oregon State University; 2013

8. Yeung SS, Yeung EW, Sakunkaruna Y, et al. Acute effects of kinesio taping on knee extensor peak torque and electromyographic activity after exhaustive isometric knee extension in healthy young adults. Clin J Sport Med. 2015; 25(3): 284-90.

9. Farthing JP, and Chilibeck PD. The effect of eccentric training at different velocities on cross-education. Eur J Appl Physiol. 2003; 89(6) : 570-7.

10. Maffiuletti NA, Aagaard P, Blazevich AJ, et al. Rate of force development: physiological and methodological considerations. Eur J Appl Physiol. 2016; 116(6): 1091-116.

11. Aagaard P, Simonsen EB, Andersen JL, et al. Increased rate of force development and neural drive of human skeletal muscle following resistance training. J Appl Physiol. 2002; 93(4): 1318-26.

12. Bojsen-Møller J, Magnusson SP, Rasmussen LR, et al. Muscle performance during maximal isometric and dynamic contractions is influenced by the stiffness of the tendinous structures. J Appl Physiol. 2005; 99(3): 986-94.

13. Enwemeka CS, Allen C, Avila P, et al. Soft tissue thermodynamics before, during, and after cold pack therapy. Med Sci Sports Exerc. 2002; 34(1) : 45-50.

14. Dewhurst S, Macalluso A, Gizzi L et al. Effects of altered muscle temperature on neuromuscular properties in young and older women. Eur J Appl Physiol. 2010; 108(3) : 451-8.

15. Warren TA, McCarty EC, Richardson AL, et al. Intraarticular knee temperature changes: ice versus cryotherapy device. Am J Sports Med. 2004; 32(2) : 441-5.

16. Kime R, Sirasawa H, Tamaki $\mathrm{H}$, et al. Effects of local cooling and heating in the triceps surae muscles during sustained isometric contraction.J Phys Fitness Sports Med. 1998; 47(1): 103-17.

17. Muraoka T, Omuro K, Wakahara T, et al. Effects of muscle cooling on the stiffness of the human gastrocnemius muscle in vivo. Cells Tissues Organs. 2008; 187(2): 152-60.

18. Selkow NM, Hogan K, Schodrof S, et al. The effect of two cooling modalities on skin and Achilles tendon temperature. Med Sci Sports Exerc. 2014; 46(5)S: 205.

19. Alegre LM, Hasler M, Wenger S, et al. Does knee joint cooling change in vivo patellar tendon mechanical properties? Eur J Appl Physiol. 2016; 116(10): 1921-9.

20. Price R, Lehmann JF. Influence of muscle cooling on the viscoelastic response of the human ankle to sinusoidal displacements. Arch Phys Med Rehabil. 1990; 71(10): 745-8.

21. Kubo K, Kanehisa H, Fukunaga T. Effects of cold and hot water immersion on the mechanical properties of human muscle and tendon in vivo. Clin Biomech. 2005; 20(3): 291-300.

22. Walker P, Amstutz HC, Rubinfeld M. Canine tendon studies. II. Biomechanical evaluation of normal and regrown canine tendons. J Biomed Mater Res. 1976; 10(1): 61-76.

23. Mense S. Effects of temperature on the discharges of muscle spindles and tendon organs. Pflugers Arch. 1978; 374(2): 159-66.

24. Abramson DI, Chu LS, Tuck S Jr, et al. Effect of tissue temperatures and blood flow on motor nerve conduction velocity. JAMA. 1966; 198(10): 1082-8. 